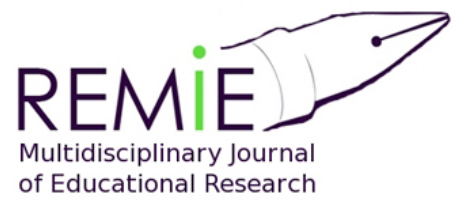

Instructions for authors, subscriptions and further details:

http://remie.hipatiapress.com

\title{
Humour-based Learning: From the Lens of Adolescents
}

Serkan Unsal ${ }^{1}$, Reyhan Agcam ${ }^{1}$ Mikail Aydemir ${ }^{2}$

1

1) Kahramanmaras Sutcu Imam University. Turkey

2) Ministry of National Education

Date of publication: February $15^{\text {th }}, 2018$

Edition period: February 2018-May 2018

To cite this article: Unsal, S., Reyhan, A., \& Aydemir, M. (2018). Humourbased LEarning: From the Lens of Adolescents. Multidisciplinary Journal of Educational Research, Vol 8(1), 29-55. doi: 10.17583/remie.2018.3169

To link this article: http://dx.doi.org/10.17583/remie.2018.3169

\section{PLEASE SCROLL DOWN FOR ARTICLE}

The terms and conditions of use are related to the Open Journal System and to Creative Commons Attribution License(CC-BY). 


\section{Humour-Based Learning: From the Lens of Adolescents}

Serkan Unsal

Kahramanmaras Sutcu Imam

University

Reyhan Agcam

Kahramanmaras Sutcu Imam

University

Mikail Aydemir

Ministry of National Education (MoNE)

(Received: 29 December 2018; Accepted: 8 February 2018; Published: 15 February 2018)

\section{Abstract}

Along with its psychological, physical and social benefits, humour has proved undeniably useful in educational contexts especially for the last sixty years. In order to close the research gap in Turkey, the current study scrutinized secondary school students' views on the educational use of humour. Accordingly, 525 students attending state secondary schools were administered the Educational Humour Scale (EHS) in order to see whether they significantly differ in their related views regarding gender and types of schools they were attending. Their responses were qualitatively analysed through Nvivo 9, and codes, sub-codes and themes were formed based on the analysis results. An approximate consensus has been reached among the students on the idea that use of humour is profoundly beneficial in education. The statistical findings have revealed that the students do not significantly differ in their views on the use of humour in education with respect to gender and types of schools they attend ( $p>.05$ ). The study ends with a few practical implications on the findings and suggestions for further research.

Keywords: humour, educational humour, secondary education 


\section{El Aprendizaje Basado en el Humor: desde la Lente de los Adolescentes}

Serkan Unsal

Kahramanmaraş Sütçü İmam

Üniversitesi
Reyhan Agcam

Kahramanmaraş Sütçü İmam

Üniversitesi

Mikail Aydemir, Ministry of National Education (MoNE)

(Recibido: 29 diciembre 2018; Aceptado: 8 febrero 2018; Publicado: 15 febrero 2018)

\section{Resumen}

Junto con sus beneficios psicológicos, físicos y sociales, el humor ha demostrado ser útil en contextos educativos, especialmente durante los últimos sesenta años. Con el fin de cerrar la brecha de investigación en Turquía, el estudio actual analizó las opiniones de los estudiantes de secundaria sobre el uso educativo del humor. En consecuencia, a 525 estudiantes que asistieron a escuelas secundarias estatales se les administró la Escala de Humor Educativo (EHS) para ver si difieren significativamente en sus puntos de vista relacionados con el género y los tipos de escuelas a las que asisten. Sus respuestas se analizaron cualitativamente a través de Nvivo 9, y se formaron códigos, subcódigos y temas en función de los resultados del análisis. Se llegó a un consenso aproximado sobre la idea de que el uso del humor es profundamente beneficioso para la educación. Los resultados estadísticos han revelado que los estudiantes no difieren significativamente en sus puntos de vista sobre el uso del humor en la educación con respecto al género y los tipos de escuelas a las que asisten ( $\mathrm{p}>$.05). El estudio finaliza con algunas implicaciones prácticas sobre los hallazgos y sugerencias para futuras investigaciones.

Palabras clave:humor, humor educativo, educación secundaria

2013 Hipatia Press

ISSN: 2014-6728

DOI: $10.4471 /$ remie.2018.3169

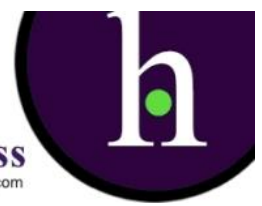


$\mathrm{T}$ $21^{\text {st }}$ century has experienced significant reforms and tendencies in education, which has raised particular questions about instructional approaches, strategies and techniques as well as role of teachers and students in learning process. One of the most prevalent questions addresses how learning could be more effective, permanent and enjoyable. In response, humour is suggested as one of the tools that help students get actively involved in the learning process and obtain pleasure from it in view of the fact that it could be efficiently employed in transmitting knowledge by "shifting the role of the students from passive to active participants of the learning environment" (Avşar, 2008). Özkara (2013) identifies humour as "a way of reasoning with its social, emotional, cognitive and linguistic components that are all meaningful". It has been depicted as a way of life interpretation (Vural, 2004), the ability to recognise the enjoyable aspects of life (Aydin, 2005), and interpretation of events from individual perspectives. A general consensus seems to exist that humour is a social phenomenon (Ruch, 1998) with its characteristics that relieve, please and entertain humans. In a similar vein, Yirci et al., (2016) advocate that it could be used in various contexts including education since it can help students focus and maintain their attention to the subject matters (Ziv, 1979), reduce tension in the classroom, alleviate boredom, disarm aggression, and stimulate students' interest (Gorham \& Christophel, 1990). The use of humour has been recommended for virtually every grade level from preschool to university, and for various subjects -including language arts, reading, math, statistics, science, and psychology (Ivy, 2013, p. 39). Namely, Blackmore (2011, p. 16) posits that children are more likely to learn and retain information if they are happy and feel secure rather than feel threatened or anxious in the classroom where humour could be used to create more relaxed learning climates. It serves such functions as encouraging students to think critically (Kazanc1, 1989), facilitating learning for students (Akkaya, 2011), and increasing their motivation to get involved in learning activities (Aç1kgöz, 2003). Likewise, Wanzer (2002) postulates that the use of humour in the classroom allows for a positive communication between teachers and students increasing students' eager to learn, which is also stated in subsequent research (Schmitz, 2002; Torok et al., 2004; Garner, 2006). It softens classroom atmosphere and creates a positive climate in the classroom allowing an appropriate learning environment (Lei et al., 2010; Jeder, 2015). In addition, it reduces stress, 
anxiety and boredom in the classroom improving teacher-student interaction, making learning fun, increasing interest to knowledge, facilitating comprehension, and making learning permanent (Torok et al., 2004; Martin, 2007; Ahern, 2008). Deiter (2000, p. 27) argues that humour is used most effectively as a presentation tool when well-planned and well-thought out, and that it can be used to increase an instructor's credibility, likability, professional image, and perhaps most importantly, teaching effectiveness. Besides, students frequently underline having a good sense of humour while describing characteristics of a good teacher (Garner, 2006). Teachers state that appropriate use of humour has a positive influence on students' learning drawing their attention. Thereby, students are considered to display higher motivation towards learning (Bolkan \& Goodboy, 2015,p. 26), and to be provided a positive learning environment (Davenport, 2015). In a similar vein, it has been associated with a more interesting and relaxed learning environment, higher instructor evaluations, greater perceived motivation to learn, and enjoyment of the course (Banas et al., 2011, p. 137). Developing the sense of humour and nurturing a quality humour both among students and teachers are ways in which school would get more value, in the sense that it would provide the necessary tools to create and maintain wellness, to stimulate thought, imagination, positive emotions etc. as goals or targets of an authentic education (Jeder, 2015, p.833).Accordingly, due to its cognitive, emotional, psychological and pedagogical benefits, the educational institutions of different levels should aim to facilitate developing a good sense of humour in students.

Review of the related literature on instructional use of humour shows that it has been investigated with various sampling groups such as school administrators, teachers and students. Namely, Savaş (2013) investigated the influence of humour activities prepared in accord with the principles of constructive approach on primary school students' academic achievement and reported that humour has positively influenced the students' success in Turkish language course. Yirci et al. (2016) scrutinized humour tendencies of school administrators and found that they do not significantly differ with respect to such variables as age, gender and type of institution they were working, and that their tendencies were not observed at the intended level. In a subsequent study, Balta (2016) reported that teachers have positive attitudes towards the use of humour in education. Concerning its use in primary 
education, Altınkurt and Y1lmaz (2011) concluded that teachers generally display a pluralistic sense of humour, and that their sense of humour differs regarding gender and area of discipline while it does not differ in terms of seniority, and age. As in the case of students, Linh (2011) highlights that the educational use of humour is perceived differently in schools located in the west (European countries and US) and Asia mentioning the finding that humour is perceived by the Chinese undergraduate students as the least important factors in the ideal Chinese personality (Yue et al., 2006) while it is considered remarkably significant in the western societies.

Stuart and Rosenfeld (1994) reported that when students viewed instructors as using no humour, they perceived the classroom as having a relatively formal classroom atmosphere -very controlled and task-focused but also low in instructor support, and that they perceived the classroom environment as non-supportive, competitive, and controlled when instructors primarily used hostile humour, even when it was minimal. Conducting a similar study with a focus on students' perception of teacher uses of humour to enact power and gain compliance, Punyanunt (1997) revealed that students' and instructors' humorous orientations are quite different, that students' perceptions did not affect their perceptions of college teachers' humour orientation, and that student humour orientations have little effect on teacher's use of humour. Makewa et al. (2011), on the other hand, concluded that the use of humour in teaching is generally good and that there is a significant, moderate relationship between the use of humour and students' rating of teachers' effectiveness; namely, teachers who use humour in teaching are generally rated effective in terms of motivation, creation of engaging lessons and anxiety reduction in students.

As for the context of higher education, Berk (1996) studied the effectiveness of 10 systematic strategies for using humour as a teaching tool: (i) humorous material on syllabi; (ii) descriptors, cautions, and warnings on the covers of handouts; (iii) opening jokes; (iv) skits/dramatizations; (v) spontaneous humour; (vi) humorous questions; (vii) humorous examples; (viii) humorous problem sets; (ix) Jeopardy!TM -type reviews for exams; and (x) humorous material on exams, and reported that students perceived the humour techniques as "very effective" or "extremely effective" in reducing their anxiety, facilitating learning, and enhancing academic performance (cited in Segrist \& Hupp, 2015). Scarborough (2014) examined behaviours 
inherent in the instructional use of humour in an online university from the student's perspective, and informed that students participating in online classes report more learning behaviours when their instructor seemingly has high humour orientation, places significant value on the use of humour in their teaching/ learning presentation and begins class with humorous material. Pham (2014) examined university teachers' and students' perceptions of the roles of humour in EFL teaching, teachers' practices of humour use, and students' response to teachers' use of humour in the context of Vietnamese higher education. The researcher found the majority of university EFL teachers and students held positive views of the use of humour in EFL teaching and believed that humour has affective and cognitive benefits for students, their learning, and the teacher-student relationship. Zhou (2015) explored engineering design students' perceptions of humour in the experiences of creativity development in Project-Organized Groups (POGs) in China, and found that humorous people are considered creative, and humour is regarded as not only a personality or communication tool, but also the outcome of applying creative ideas in design practice. The students are also of the opinion that it is the immediate ability to create using language in ongoing communication contexts, and mainly used to keep individuals' harmonious relationship with the group. In a study carried out with international students in the US, informed that the materials including humour elements improved students' understanding of the presented topics and stimulated their interest in learning.

Çakıroğlu and Erdoğdu (2016) stress that research on the use of humour in education and psychology in Turkey is relatively restricted. In most of the studies, humour has been investigated in face-to-face education and teachercentred education contexts (Vural, 2004; Aslan, 2006; Topçuoğlu, 2007; Yerlikaya, 2007; Avşar, 2008; Sümer, 2008; Yard1mc1, 2010; Özkara, 2013; Savaş, 2013; Topal, 2013; Balta, 2016; Yirci et al., 2016). It has also been concluded that most of them were literature review-based rather than applied research, and that little research has been carried out with a focus on students' views toward the use of humour in education (Ay, 2011). In this regard, Balta (2016) highlights the need for revealing students' views and attitudes on the instructional use of humour because of the influence of humour on their learning. Hence, this particular study is considered to contribute to extensive use of humour in education. It is specifically motivated to reveal students' 
views on the use of humour in learning process, and to address the following research questions.

1. What are the students' views on the use of humour in educational settings?

2. Do the students' views on the use of humour in educational settings significantly differ regarding types of schools they attend?

3. Do the students' views on the use of humour in educational settings significantly differ regarding grades they are enrolled?

4. Do the students' views on the use of humour in educational settings significantly differ regarding gender?

The following section is intended to offer methodological outline of the study adopted for the purpose of seeking answers to these questions.

\section{Research Design}

In this section, sampling of the research, data collection instruments as well as their development process, and data analysis are identified.

\section{Participants}

A total of 505 students attending secondary schools in different types of state schools affiliated to the Ministry of National Education (MoNE) in Turkey in Academic Year 2016-2017 voluntarily participated in this research. At the time of data collection, they were studying at different grades. Table 1 provides their distribution across schools and gender, and demographic information.

As illustrated in Table 1, approximately $63 \%$ of the participants were female and slightly over $37 \%$ were male. A relatively balanced distribution was achieved among types of secondary schools they were attending (Anatolian High School: 33.7\%; Science High School: 33.6\%; Social Sciences High School: 35\%). Lastly, the number of the students did not dramatically differ across grade levels. Method of data collection and analysis are identified in the following section. 
Table 1:

Demographic information about participants

\begin{tabular}{llll}
\multicolumn{2}{l}{ Variables } & $\boldsymbol{f}$ & $\mathbf{\%}$ \\
\hline Gender & Female & 325 & 62,9 \\
& Male & 200 & 37,1 \\
\hline School & Anatolian High School & 172 & 32,7 \\
Type & & 177 & 33,7 \\
& Science High School & 176 & 33,6 \\
& Social Sciences High School & 183 & 35,0 \\
Grade & $9^{\text {th }}$ Grade & 177 & 33,7 \\
& $10^{\text {th }}$ Grade & 165 & 31,3 \\
& $11^{\text {th }}$ Grade & $\mathbf{5 2 5}$ & $\mathbf{1 0 0}$
\end{tabular}

Materials and Procedure. In order to elicit students' views on the use of humour in education, the Educational Humour Scale (EHS, henceforth) comprising 20 likert-type was developed by the researchers. In addition, students were posed an open-ended item for the purpose of obtaining their related views in more detail. It is noteworthy that the scale items were developed after an extensive literature review on the use of humour in educational settings. Considering the cognitive, social, and psychological characteristics of the target mass into account, a pool of 24 likert-type items were initially created after examining the instrumentation used in Garner (2006), Wanzer (2002), Blackmore (2011), Savaş (2013), and Yirci et al. (2016). Subsequently, content validity of the tool was assessed through expert opinion from two faculty members at a state university in Turkey who are specialized in programme development and instruction, and who have published several works on humour-based learning. In accord with their views, four items were excluded from the scale as they were reported close in meaning and/ or somewhat irrelevant to the other items.

Construct validity of the scale was assessed through exploratory and confirmatory factor analyses, respectively. The data set was found appropriate for factor analysis by the results of Bartlett's sphericity test $(\mathrm{p}<.05 . \mathrm{df}=190, \chi 2=5262.392)$, and the KMO index (Kaiser-Mayer-Olkin) (.948), which are both significant in the literature (Pallant, 2005). Table 2 indicates results of the exploratory factor analysis of the scale. 


\section{Table 2:}

Factor loads of the Educational Humour Scale (EHS)

\begin{tabular}{|c|c|c|}
\hline & \multirow[t]{2}{*}{ Items } & $\begin{array}{l}\text { Factor } \\
\text { Load }\end{array}$ \\
\hline & & 1 \\
\hline 1 & Increases course success. & ,754 \\
\hline 2 & Increases the motivation to engage in learning process. & ,751 \\
\hline 3 & Promotes active engagement in class. & ,735 \\
\hline 4 & Increases self-efficacy to learn. & 729 \\
\hline 5 & Brings teachers and students closer. & ,719 \\
\hline 6 & $\begin{array}{l}\text { Creates a positive learning environment by reducing tension in } \\
\text { the classroom. }\end{array}$ & ,713 \\
\hline 7 & Makes learning enjoyable. & ,713 \\
\hline 8 & Makes learning easier. & ,702 \\
\hline 9 & Overcomes negative prejudices for the course. & 689 \\
\hline 10 & Makes subjects matters interesting. & ,689 \\
\hline 11 & Makes courses appealing to students. & ,683 \\
\hline 12 & Increases student motivation. & ,682 \\
\hline 13 & Makes learning permanent. & ,675 \\
\hline 14 & Facilitates understanding of challenging concepts. & ,664 \\
\hline 15 & Increases attention to courses. & ,643 \\
\hline 16 & Encourages collaboration among students in learning. & ,639 \\
\hline 17 & $\begin{array}{l}\text { Establishes trust between teacher and students and among } \\
\text { students. }\end{array}$ & 624 \\
\hline 18 & Encourages students to express themselves without hesitation. & 602 \\
\hline 19 & Increases time devoted to (preparation for) courses. & 579 \\
\hline 20 & Facilitates linking newly-learnt information with real life. & 5,547 \\
\hline
\end{tabular}

\section{Eigenvalue 9.216}

Total Variance $\mathbf{4 6 . 0 8 2 \%}$

As shown in Table 2, factor loads of scale items ranges from .547 to .754 . It is stated in the literature that factor loads between .30 and .40 could be established as lower cut-off point (Can, 2017, p. 317; Büyüköztürk, 2017, p. 133). In this study, it was set as .50 , and no items were excluded from the scale since their factor loads were counted above this value. Mplus programme was utilized for calculations of the confirmatory factor analysis. The related Path diagram and the results are shown in Figure 1. 


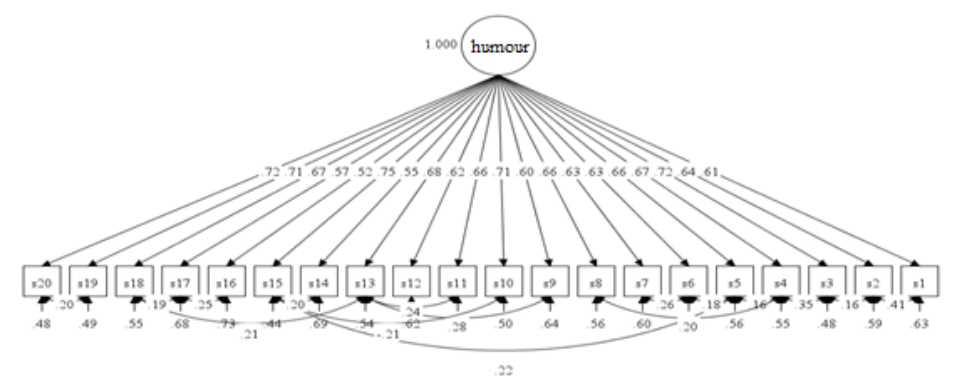

Figure 1. CFA Path diagram for the educational humour scale

First of the fit indices of CFA models is the chi-square statistics (x2), which is calculated by proportioning to degree of freedom (df). The index indicates excellent fit if $\mathrm{x} 2 / \mathrm{sd}$ is counted less than 3 , and acceptable fit if counted less than 5. Accordingly, the index indicates excellent fit in this study as the proportion was counted lower than $3(444.341 / 154=2.885)$ (Suimer, 2000). Table 3 provides the statistical results in detail.

Table 3:

Fit indices of the educational humour scale

\begin{tabular}{llll}
$\begin{array}{l}\text { Fit } \\
\text { Indices }\end{array}$ & Excellent Fit & Acceptable Values & $\begin{array}{l}\text { Fit Values of the } \\
\text { Scale }\end{array}$ \\
\hline CFI & $0.95 \leq \mathrm{CFI} \leq 1.00$ & $0.90 \leq \mathrm{CFI} \leq 0.95$ & 0.944 \\
NNFI(TL & $0.95 \leq \mathrm{NNFI}(\mathrm{TLI}) \leq 1.00$ & $0.90 \quad 0.95 \quad \mathrm{NNFI}(\mathrm{TLI}) \leq$ & 0.931 \\
I) & $0.00 \leq \mathrm{SRMR} \leq 0.05$ & $0.05 \leq \mathrm{SRMR} \leq 0.10$ & 0.041 \\
SRMR & $0.00 \leq \mathrm{RMSEA} \leq 0.05$ & $0.05 \leq \mathrm{RMSEA} \leq 0.08$ & 0.061
\end{tabular}

Table 3 suggests that Standardised Root Mean Square Residual (SRMSR) was counted .041, that Root Mean Square Error of Approximation (RMSEA) was .061, that Non-Normative Fit Index (NNFI) was .0931, and that Comparative Fit Index (CFI) was .944. That is, fit indices of the scale were found excellent or acceptable, indicating that its construct validity and compliance validity were provided (Sümer, 2000; Y1lmaz \& Çelik, 2009). 
The Alpha model was used to assess the reliability of the scale, and Cronbach's Alpha reliability value was calculated .936. Total correlation values of the scale items are presented in Table 4.

Table 4

Item correlation values for the educational humour scale

\begin{tabular}{|c|c|c|}
\hline No & Items & $\begin{array}{l}\text { Corrected total } \\
\text { item correlation }\end{array}$ \\
\hline 1 & Increases attention to courses. &, 595 \\
\hline 2 & Increases student motivation. & 635 \\
\hline 3 & Increases the motivation to engage in learning process. & ,704 \\
\hline 4 & Makes learning enjoyable. & 659 \\
\hline 5 & Makes learning easier. & 657 \\
\hline 6 & Makes learning permanent. & 629 \\
\hline 7 & Facilitates understanding of challenging concepts. & 622 \\
\hline 8 & Makes subjects matters interesting. & ,642 \\
\hline 9 & Establishes trust between teacher and students and among students. &, 575 \\
\hline 10 & $\begin{array}{l}\text { Creates a positive learning environment by reducing tension in the } \\
\text { classroom. }\end{array}$ & ,666 \\
\hline 11 & Makes courses appealing to students. & 634 \\
\hline 12 & Encourages collaboration among students in learning. & 601 \\
\hline 13 & Brings teachers and students closer. & 676 \\
\hline 14 & Increases time devoted to (preparation for) courses. &, 538 \\
\hline 15 & Increases course success. & ,724 \\
\hline 16 & Facilitates linking newly-learnt information with real life. &, 508 \\
\hline 17 & Encourages students to express themselves without hesitation. &, 560 \\
\hline 18 & Overcomes negative prejudices for the course. & ,645 \\
\hline 19 & Increases self-efficacy to learn. & 692 \\
\hline 20 & Promotes active engagement in class. & 697 \\
\hline
\end{tabular}

Total correlation of EHS items ranges from .508 to .724 . No items were excluded from the scale since no correlation value was found below the lower cut-off point .50 . The following section is intended to provide information about data analysis. 


\section{Data Analysis}

The data were collected through EHS that consisted of likert-type items pointed from 1 (strongly disagree) to 5 (strongly agree). Levels of agreement and related score intervals are depicted in Table 5.

Table 5:

Levels of agreement and score intervals in EHS

\begin{tabular}{ll} 
Score Intervals & Levels of Agreement \\
\hline $1.00-1.79$ & Strongly disagree \\
$1.80-2.59$ & Disagree \\
$2.60-3.39$ & Undecided \\
$3.40-4.19$ & Agree \\
$4.20-5.00$ & Strongly agree
\end{tabular}

Within the framework of the aims of the present study, the quantitative data elicited from the participants' responses to likert-type items were analysed through the independent samples t-test and the one-way variance analysis (ANOVA), and the qualitative data obtained from participants' responses to the open-ended item were analysed through content analysis. Their responses were also analysed and modelled through NVivo 9, a computer-assisted qualitative data analysis programme. Themes, codes, subcodes, and frequency values obtained from data analysis were presented in the form of a model. The related results are outlined and discussed in the following section.

\section{Findings}

The first research question of the study was to reveal the students' views on the use of humour in educational settings. The related results are given in Table 6 . 
Table 6:

Students' views on the use of humour in education

\begin{tabular}{|c|c|c|c|c|}
\hline No & Scale Items & $\overline{\boldsymbol{X}}$ & ss & $\begin{array}{l}\text { Level } \\
\text { agreement }\end{array}$ \\
\hline 1 & Increases attention to courses. & 3,97 & 1,077 & Agree \\
\hline 2 & Increases student motivation. & 4,22 & 4,02 & Strongly Agree \\
\hline 3 & $\begin{array}{l}\text { Increases the motivation to engage in learning } \\
\text { process. }\end{array}$ & 4,28 & 3,97 & Strongly Agree \\
\hline 4 & Makes learning enjoyable. & 4,56 & 0,757 & Strongly Agree \\
\hline 5 & Makes learning easier. & 4,04 & 0,991 & Agree \\
\hline 6 & Makes learning permanent. & 4,05 & 1,029 & Agree \\
\hline 7 & Facilitates understanding of challenging concepts. & 4,01 & 1,088 & Agree \\
\hline 8 & Makes subjects matters interesting. & 4,38 & 0,912 & Strongly Agree \\
\hline 9 & $\begin{array}{l}\text { Establishes trust between teacher and students and } \\
\text { among students. }\end{array}$ & 4,14 & 1,049 & Agree \\
\hline 10 & $\begin{array}{l}\text { Creates a positive learning environment by reducing } \\
\text { tension in the classroom. }\end{array}$ & 4,32 & 0,903 & Strongly Agree \\
\hline 11 & Makes courses appealing to students. & 4,34 & 0,992 & Strongly Agree \\
\hline 12 & $\begin{array}{l}\text { Encourages collaboration among students in } \\
\text { learning. }\end{array}$ & 3,84 & 1,093 & Agree \\
\hline 13 & Brings teachers and students closer. & 4,28 & 0,931 & Strongly Agree \\
\hline 14 & Increases time devoted to (preparation for) courses. & 3,43 & 1,277 & Agree \\
\hline 15 & Increases course success. & 3,86 & 1,025 & Agree \\
\hline 16 & $\begin{array}{l}\text { Facilitates linking newly-learnt information with } \\
\text { real life. }\end{array}$ & 4,02 & 1,058 & Agree \\
\hline 17 & $\begin{array}{l}\text { Encourages students to express themselves without } \\
\text { hesitation. }\end{array}$ & 4,10 & 1,077 & Agree \\
\hline 18 & Overcomes negative prejudices for the course. & 4,07 & 1,015 & Agree \\
\hline 19 & Increases self-efficacy to learn. & 4,01 & 1,031 & Agree \\
\hline \multirow[t]{2}{*}{20} & Promotes active engagement in class. & 4,22 & 0,955 & Strongly Agree \\
\hline & TOTAL & 4,10 & 0,678 & Agree \\
\hline
\end{tabular}

The participant students' tend to strongly agree and agree on 8 and 12 items, respectively. They generally agreed to the items on the scale $\left(X^{-}=4.10\right)$. They mostly agreed to the item "Humour makes learning enjoyable" $\left(\mathrm{X}^{-}=4.56\right)$ and least to the item "Increases time devoted to (preparation for) courses" $\left(\mathrm{X}^{-}=3.43\right)$. The results of the independent samples 
t-test that was administered to see whether students' views on the use of humour in education differ regarding gender are presented in Table 7.

Table 7:

Students' views on the use of humour in education regarding gender

\begin{tabular}{|c|c|c|c|c|c|c|}
\hline Gender & $\mathrm{N}$ & $\bar{X}$ & ss & sd & $\mathrm{t}$ & $\mathrm{p}$ \\
\hline Female & 317 & 4,11 & 0,663 & \multirow{2}{*}{503} & \multirow{2}{*}{0,297} & \multirow{2}{*}{0,147} \\
\hline Male & 188 & 4,09 & 0,704 & & & \\
\hline
\end{tabular}

As illustrated in Table 7, no statistically significant difference was found between female and male students in terms of their views on the use of humour in education ( $p>05)$. The results of one-way variance analysis (ANOVA) with respect to school types the students were attending are demonstrated in Table 8.

Table 8:

ANOVA results for students' views on the use of humour in education regarding school

\begin{tabular}{|c|c|c|c|c|c|c|c|}
\hline School Type & $N$ & $\overline{\boldsymbol{X}}$ & ss & $s d$ & $\begin{array}{l}\text { Mean } \\
\text { Squares }\end{array}$ & $\boldsymbol{F}$ & $p$ \\
\hline Anatolian High School & 165 & 4,11 & ,646 & &, 521 & & \\
\hline Science High School & 170 & 4,04 & ,667 & 2 & ,460 & 1,132 & ,323 \\
\hline $\begin{array}{l}\text { Social Sciences High } \\
\text { School }\end{array}$ & 170 & 4,15 & ,717 & 502 & & & \\
\hline TOTAL & 505 & 4,10 & 678 & 504 & & & \\
\hline
\end{tabular}

The test results have shown that the students do not significantly differ in their views on educational use of humour with respect to types of secondary schools they were attending $(\mathrm{F}=1,132 ; \mathrm{p}>0.05)$. Lastly, ANOVA results for their related views regarding grades they were studying are given in Table 9. 
Table 9:

Students' views on the use of humour in education regarding grade

\begin{tabular}{lccccccc} 
Grades & $\mathbf{N}$ & $\overline{\boldsymbol{X}}$ & Ss & sd & $\begin{array}{c}\text { Mean } \\
\text { Squares }\end{array}$ & $\mathbf{F}$ & $\mathbf{p}$ \\
\hline $9^{\text {th }}$ Grade & 177 & 4,06 & 0,666 & & 0,201 & & \\
$10^{\text {th }}$ Grade & 171 & 4,13 & 0,658 & 2 & 0,461 & 0,436 & 0,647 \\
$11^{\text {th }}$ Grade & 157 & 4,12 & 0,714 & 502 & & & \\
\hline TOPLAM & 505 & 4,10 & 0,678 & 504 & &
\end{tabular}

As seen in Table 9, the means related to the educational use of humour were compared with regard to grades students were studying, and it was concluded that the difference between the squares were found statistically insignificant $(\mathrm{F}=0,436 ; \mathrm{p}>.05)$.

In order for a comprehensive analysis of students' views on the educational use of humour, they were asked whether they think humour should be used in education and requested to explain their answers briefly at the end of the scale. It is noteworthy that $75 \%$ of the participants responded to this item and that slightly over $46 \%$ of them expressed positive views on the use of humour in education, $3.4 \%$ reacted to it negatively while approximately $25 \%$ expressed conditionally positive opinions on it. The themes related to their responses and explanations are illustrated in Figure 2.

As could be seen in Figure 2, students' views on educational use of humour were coded as positive views $(f=419)$, negative views $(f=61)$, and conditionally positive views $(f=163)$. Such sub-themes as contribution to learning process $(f=268)$, psychological contribution $(f=163)$, and contribution to class management $(f=18)$ were created under the theme of positive views. Based on students' responses, the following codes were formed under the subtheme of contribution to learning process: obtaining pleasure from the course $(f=110)$, increasing attention $(f=24)$, active participation/ engagement in class $(f=30)$, permanent learning $(f=28)$, increasing course success $(f=24)$, and making learning easier $(f=22)$. Codes drawn from the subtheme psychological contribution could be listed as increasing attention to courses $(f=78)$, overcoming negative prejudices for 
the course $(f=4)$, bringing teacher and students closer $(f=50)$, increasing motivation $(f=17)$, and inspiring self-confidence $(f=14)$. The following are the extracts driven from students who positively responded to the question 'Do you think humour should be used in education?"

"Yes, I do. When our teacher uses humour in the classroom, I feel closer to her, and this helps me ask questions without hesitation" (P-3)

"Yes. I retain what learned in class longer when humour is used. I love the courses in which humour is used. I also believe that it increases our motivation and brings us (students) closer. Finally, students tend to respect more to the teachers who uses humour, and to do their best to fulfil responsibilities assigned by them" (P-12)

"Humour should be used in the classroom because it plays an important role in overcoming our negative prejudices toward the courses, and creates a more enjoyable learning environment, which alleviates boredom and monotony in the classroom" (P-125)

"We simply do not count the minutes for the class to end when humour is used" (P-337)

The participants who conditioned their positive views on the use of humour in education stated that it should be used cautiously $(f=62)$, when needed (49), efficiently $(f=36)$, and when it is not offending $(f=8)$. The following are taken from their responses to the item in concern.

"I find it as a positive component as long as it is not offending. Then, it helps us love the school and courses when we have fun while learning" (P48)

"It should be used during classes within reason. The classes will be underestimated by the students and disturbs the discipline in the classroom if humour is overused" (P-67)

"I strongly believe that it should be used in the classroom on condition that it is used at the right time. I, personally, listen to the subject matters more carefully and attentively, feel more open to learning, and leave the class in a good mood when our teachers use humour" (P-246)

"I believe it should be used only by the teachers with a good sense of humours; otherwise, it will decrease attention to the subjects, and be timewasting" (P-311) 


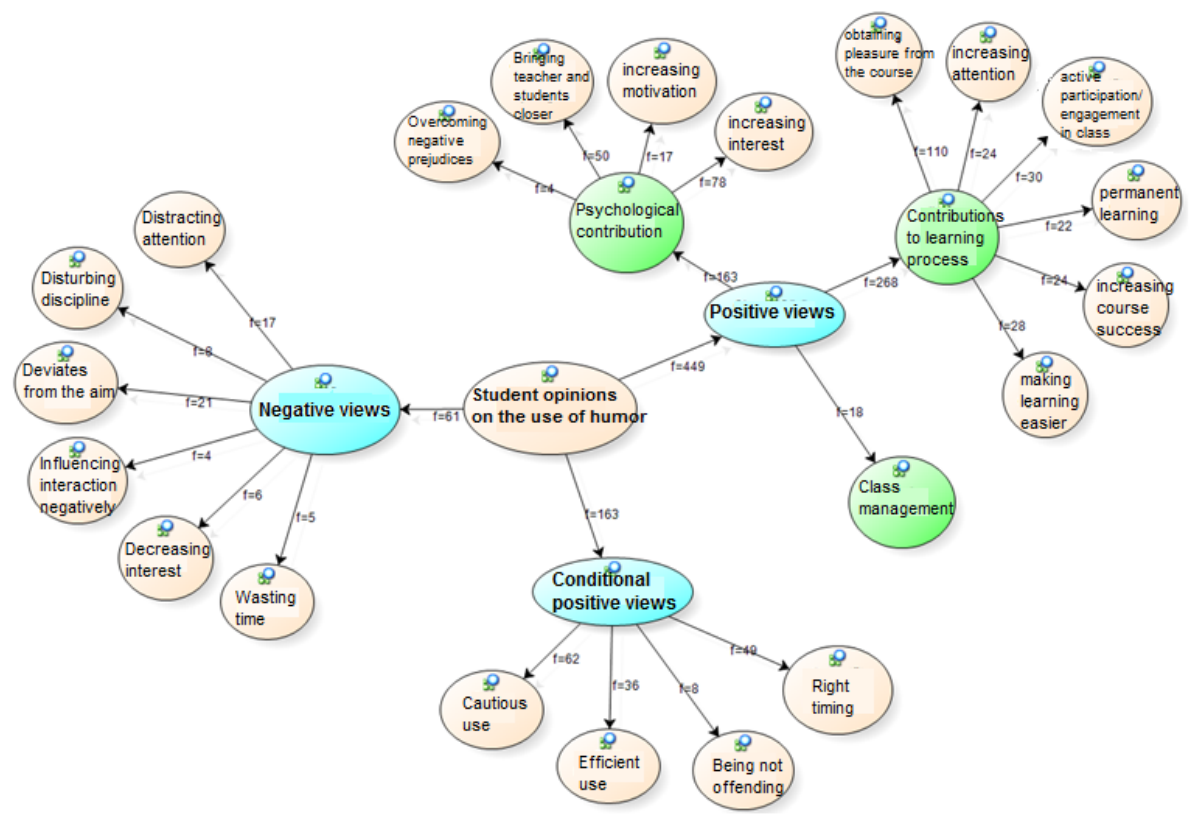

Figure 2. Students' views on educational use of humour

Lastly, those who reported it should be avoided in the classroom since it deviates from the aim $(f=21)$, distracts attention $(f=17)$, disturbs discipline $(f=8)$, reduces attention $(f=7)$, wastes time $(f=6)$, and influences interaction negatively $(f=4)$. The following extracts are intended to exemplify them.

"I do not agree with this idea since it disrupts the classes" (P-51)

"No. I believe it might be offending especially among students" (P-74)

"I do not believe that it should be used in the classroom because I generally lose my attention to the subjects, and there is so much noise in the classroom because everybody is trying to make fun of each other." (P-118)

"It should not be used in the classroom because it decreases students" attention and causes loss of discipline” (P-220) 
The following section includes discussion on the above-mentioned findings of the research, conclusions, and practical implications for teachers and teacher trainers.

\section{Discussion, Conclusion and Practical Implications}

In accord with the total values of scale items on educational use of humour have revealed that they display a positive approach in this concern. This finding overlaps with Topal (2013), who reported primary school students and teachers have positive perceptions on humour, respectively. No statistically significant difference was found in students' views on the educational use of humour concerning gender, which is also in line with Topal (2013). The results indicated that they significantly differ with respect to types of secondary schools they were attending at the time of the study, confirming Ay (2011) who concluded students studying at Anatolian high schools have more positive beliefs on humour than those attending vocational high schools.

Another finding of the study is that the secondary school students do not significantly differ in their views on the educational use of humour with respect to grades they were enrolled. This finding seems to contradict with Topal (2013), who informed that $8^{\text {th }}$ graders (senior students in primary education in Turkey, 2017) have more positive views on humour than the students attending lower grades, and attributes it to the age factor. Nonetheless, our findings indicated that $10^{\text {th }}$ and $11^{\text {th }}$ graders reported slightly more positive views on the educational use of humour as opposed to $9^{\text {th }}$ graders.

The current research yielded findings that confirm previous research (Berk, 1996;Aydın, 2005; Oruç, 2010; Savaş, 2013; Scarborough, 2014), who concluded humour increases academic success of the students. Likewise, our findings approve the ones previously informed by various scholars (Stuart \& Rosenfield, 1994; Berk, 1996; Schmitz, 2002; Garner, 2006; Banas et al., 2011; Torok et al., 2004; Blackmore, 2011; Makewa et al., 2011; Pham, 2014; Bolkan \& Goodboy, 2015; Davenport, 2015) who found that humour increases interest, attention, and motivation to the class, and increases student success. Oruç (2006) contends that humour provides better learning drawing students' attention, making learning enjoyable, 
reducing anxiety in the learning environment, improving teacher-student interaction and social interactions among students. This particular view is supported with the present findings of our study considering the students' such responses as "use of humour in education brings teacher and students closer and increases interest and motivation to learn". Blackmore (2011) concludes that humour has an important role in building positive learning environments. All in all, findings reported in the current and previous studies have demonstrated that humour has academic, social and psychological benefits for the students during the educational process. It might be attributed to its power to make instructors more likable, approachable, facilitate comprehension, increase attentiveness, improve creativity, and promote social relationships (Lei et al., 2010, 326), and to create a positive social dimension amongst peers (Leslie, 2015). Similarly, Topçuoğlu (2007) attributes it to the fact that humour gives physiological and emotional relaxation to the students making learning faster and more permanent and increases interest and attention to classes. When considering the participants of the present study were secondary school students who are supposed to take a total of 40 hours classes a week, humour could be recommended as a beneficial tool in overcoming boredom in the classroom. The idea that humour influences teachers' in-class performance and their interaction with students (Stuart \& Rosenfield, 1994; Schmitz, 2002; Lei et al, 2010; Altinkurt \& Y1lmaz, 2011; Leslie, 2015) is supported with the finding humour brings teacher and students closer, which was revealed in the current research. Those who conditioned their positive views on the educational use of humour stated such conditions as cautious use while those who reported negative views had several hesitations about the use of humour in education such as distracting attention, disturbing discipline, and decreasing attention. This finding confirms Oruç (2010) who warns that it might deviate from the aim and disturb the discipline in the classroom. Hence, students' understanding of humour could be taken into consideration, and it should be avoided when it is offending and harmful to self-respect (Berk, 1996; Topçuoğlu, 2007). Presence of the students who reported negative views for the educational use of humour might be attributed to that it is known as a fun element rather than a tool to be used in learning process. It could also be accounted for adverse experiences between teacher and students and/ or among students, which approves Kaya (2011). In this regard, Berk (1996, p. 88) suggests that 
strategies for using humour must be planned well and executed systematically to achieve specific outcomes, and that both content-specific and generic humorous material tailored to the characteristics of each class can be effective in appropriate applications. The researcher also recommends that a wide range of low-risk humour techniques could be very effective in reducing anxiety and improving learning and performance especially when two or more senses are involved (visual and oral senses).

Many studies on the use of humour in workplace/ school have revealed that it is, by and large, initiated by those in charge -managers at workplace, and principals and teachers in educational settings. Besides, Fovet (2009) acknowledges that the in-depth research in the field of human resources indicated strong correlation between employees' perception of good leadership and superiors' use of humour. Having a good sense of humour has frequently been reported among top characteristics and qualities of effective teachers. So, when considered the initiator of affiliative humour as leaders in the classroom, the teachers can shape a behavioural strategy with the aim of facilitating interpersonal closeness and relationship satisfaction in a way that is affirming to self and the others. They also can use it as a tool to enhance the curriculum and defuse discipline problems as the students are motivated to listen and read something humorous and often unaware that they are drawing conclusions, making inferences and predictions. Hence, in accord with the findings reached in this study and taking the fact that classroom humour is mostly initiated by teachers into consideration, the following practical implications have been developed for teachers and curriculum/ textbook designers even though it principally addressed secondary school students' opinions on the instructional use of humour.

1. Teachers could be suggested to use humour as "a potential vehicle for the introduction of active learning in a classroom setting, as judicious use of humour may lead to a more relaxed learning atmosphere and greater student engagement".

2. They might be offered in-service training courses for effective and relevant use of humour in education. Alternatively, Deiter (2000)suggests teachers to spend some time before each class actually thinking about humorous material that might be used, to select 
humour that they are comfortable with, and to form a humour file including materials taken from newspapers, magazines, books, radio and TV shows, humour journals and newsletters, the internet, as well as other people.

3. Curriculum/textbook designers are recommended to integrate humour elements into the existing curricula and textbooks in order to make learning fun and permanent.

4. The students' views on the educational use of humour and its correlation with their attitudes toward courses, academic achievement, and their interaction with teachers could be elicited. Subsequently, taking the learning outcomes in the curriculum, they might be asked to prepare and bring materials including fun elements into the classroom.

5. Humour-based learning should be encouraged from pre-school to higher education for more effective use of humour as an instructional tool.

All in all, findings of the present study could not be generalised due to a number of reasons. Accordingly, the limitations of the study and a few suggestions are identified in the following section.

\section{Limitations \& Suggestions for Further Research}

This study is restricted to the investigation of Turkish secondary school students' views on the educational use of humour through a questionnaire developed by the researchers. It might be extended to explore views of students attending educational institution of different levels (primary and higher education) in different countries. It might also be furthered to elicit their attitude towards the use of humour in their learning through different data collection strategies such as in-class observation, video-recording, and/ or interview. Lastly, further studies could investigate to what extent humour is included in real learning settings using such instrumentation as classroom observation. 


\section{References}

Açıkgöz, K. (2003). Effective Learning and Teaching. İzmir: Eğitim Dünyası Yayınları.

Ahern, T. R. (2008). Undergraduate nursing students' experiences of humor in the classroom. The University of Wisconsin. Retrieved from https://minds.wisconsin.edu/handle/1793/32214

Akkaya, A. (2011). Grammar Teaching through Caricatures (Doctoral

Dissertation). Retrieved from

https://tez.yok.gov.tr/UlusalTezMerkezi/tezSorguSonucYeni.jsp

Altınkurt, Y. \& Yılmaz, K. (2011). Primary school teachers' senses of humour. PEGEM Education Journal, 1(2), 1-8.

Aslan, H. (2006). Investigating the Humour Style of Teachers who Work in Secondary Education Schools according to their Level of Learned

Resourcefulness(Master's thesis). Retrieved from

https://tez.yok.gov.tr/UlusalTezMerkezi/tezSorguSonucYeni.jsp

Avşar, V. (2008). Teachers' attitudes towards humour in education.

(Master's thesis). Retrieved from

https://tez.yok.gov.tr/UlusalTezMerkezi/tezSorguSonucYeni.jsp

Ay, Ö. (2011). Explanatory Role of Humour Styles and Creativity Level of

High School Students on their Life Satisfaction Level (Master's thesis).

Retrieved from

https://tez.yok.gov.tr/UlusalTezMerkezi/tezSorguSonucYeni.jsp

Aydin, A. (2005). Nurse and humor. Çukurova University Journal of

Nursing School, 9(1), 1-5.

Balta, E. E. (2016). Teachers' Attitudes towards Humor in Education.

Elementary Education Online, 15(4), 1268-1279. doi:

10.17051/io.2016.64984

Banas, J. A., Dunbar, N., Rodriguez, D., \& Liu, S. J. (2011). A review of humor in educational settings: Four decades of researcher. Communication Education, 60(1), pp. 115-144. doi: 10.1080/03634523.2010.496867

Berk, R. A. (1996). Student ratings of 10 strategies for using humor in college teaching. The Journal on Excellence in College Teaching, 7(3), 71-92. Retrieved from https://eric.ed.gov/?id=EJ570438 
Blackmore, A. J. (2011). To Joke or not to Joke: Some Upper-Secondary Students' Perceptions and Experiences of Humour in the Classroom. University of Halmstad.

Bolkan, S. \& Goodboy, A. K. (2015). Exploratory theoretical tests of the instructor humor-student learning link. Communication Education, 64, 45-64. doi:10.1080/03634523.2014.978793

Büyüköztürk, S. (2010). Handbook of Data Analysis for Social Sciences (1 $1^{\text {th }}$ Edition). Ankara: Pegem Akademi.

Can, A.(2016). Quantitative Data Analysis in Scientific Research Process through SPSS ( $4^{\text {th }}$ Edition). Ankara: Pegem.

Çakıroğlu, Ü. \& Erdoğdu, F. (2016). Tendencies in Research on the Use of Humor in Leaning Process. $4^{\text {th }}$ International Instructional Technologies \& Teacher Education Symposium: Rediscover Learning with Digital Learners. Elazığg, Turkey, 6-8 October 2016.

Davenport, D. C. (2015). Examining peer perceptions of humorous communication in the college classroom (Master's thesis). Theses and Dissertations--Communication. 42. Retrieved from https://uknowledge.uky.edu/comm_etds/42

Deiter, R. (2000). The use of humor as a teaching tool in the college classroom. NACTA Journal, 20-28. Retrieved from https://www.nactateachers.org/attachments/article/604/Ron_Deiter_NA CTA_Journal_June_2000.pdf

Garner, R. L. (2006). Humor in pedagogy: How ha-ha can lead to aha! College Teaching, 54(1), 177- 180. doi: 10.3200/CTCH.54.1.177-180 Gorham, J. \& Christophel, D. M. (1990). The relationship of teachers' use of humor in the classroom to immediacy and student learning. Communication Education, 39(1), pp. 46-62. Retrieved from https://www.uab.edu/Communicationstudies/richmond_files/Richmond \%20Humor\%20in\%20Classroom.pdf

Ivy, L. L. (2013). Using Humor in Classroom. Education Digest. 79(2), pp. 54-57. Retrieved from https://search.proquest.com/openview/fc71a0e5ea5e1411f021f87e22d0d $8 \mathrm{~cd} / 1$ ?pq-origsite $=$ gscholar $\& \mathrm{cbl}=25066$

Jeder, D. (2015). Implications of using humor in the classroom. ProcediaSocial and Behavioral Sciences, 180, 828-833. doi:10.1016/j.sbspro.2015.02.218 
Kaya, S. (2011). The views of teachers and students on the use of humour as a strategy in the teaching of art(Master's thesis). Retrieved from https://tez.yok.gov.tr/UlusalTezMerkezi/tezSorguSonucYeni.jsp

Kazanc1, O. (1989). Educational Psychology: From Theories and Principles to Practice. Eğitim Ankara: Kazancı Kitap Ticaret. Kocaarslan, M. (2012). Diagnostic Branched Tree Technique and its Use in the Unit Called Change and Diagnosis of Matter in the Program of Science and Technology at Fifth Grade. Mustafa Kemal University Journal of Social Sciences Institute, 9(18), 269-279. Retrieved from https://www.researchgate.net/publication/259465949

Lei, S. A., Cohen, J. L. \& Russler, K. M. (2010). Humor on learning in the college classroom: Evaluating benefits and drawbacks from instructors' perspectives. Journal of Instructional Psychology, 37(4). George Uhlig Publisher. ISSN: 0094-1956.

Leslie, C. (2015). Humour in peer interaction. e-TALS: An e-Journal of Teacher Education and Applied Language Studies, 6, pp. 51-67. doi:

10.1515/eteals-2016-0004

Linh, P. T. H. (2011). Teacher's Humor Use in the Classroom and Students' Perceptions of Its Effectiveness and Appropriateness (Bachelor's thesis). Retrieved from https://tr.scribd.com/document/62694137/Teacher-s-Humor-Use-in-theClassroom-and-Students-Perceptions-of-Its-Effectiveness-andAppropria

Makewa, L. N., Role, E. \& Genga, J. A. (2011). Teachers' Use of Humor in Teaching and Students' Rating of Their Effectiveness. International Journal of Education, 3(2), 1-17. doi:10.5296/ije.v3i2.631

Martin, R. A. (2007). The Psychology of Humor: An integrative approach. London: Elsevier.

Oruç, Ş. (2006). Humour in Teaching Social Sciences (PhD Dissertation), Gazi University, Ankara. Retrieved from https://tez.yok.gov.tr/UlusalTezMerkezi/tezSorguSonucYeni.jsp

Oruç, Ş. (2010). The Effect of Humour Usage in Social Science Teaching on Academic Success and Attitude of Students. Mehmet Akif Ersoy Institute of social Sciences Journal, 2(3), 58.

Özkara, Y. (2013). Utilization from Humour Elements in Primary School Turkish Teaching Period. Milli Folklor, 25(100), 182-188. Retrieved from 


\section{https://www.researchgate.net/publication/288155909_Utilization_from_}

humour_elements_in_primary_school_Turkish_teaching_period

Pallant, J. (2005). SPSS Survival Manuel: A Step by Step Guide to Data.

Australia: Ligare.

Pham, H. N. H. (2014). The use of humour in EFL teaching: A case study of

Vietnamese university teachers' and students' perceptions and practices

(Doctoral dissertation). Retrieved from

http://www.canberra.edu.au/researchrepository/items/f6fd3a90-c261-

4768-9650-556354aac708/1/

Punyanunt, N. M. (1997). The Effects of Humor on Perceptions of

Compliance-Gaining in the Classroom (Master's thesis). Retrieved from https://ttu-ir.tdl.org/ttu-

ir/bitstream/handle/2346/15060/31295012203211.pdf?sequence=1

Ruch, W. (1998). Exploring paradigms: The study of gender and sense of humour near the end of $20^{\text {th }}$ century. In Ruch, Willibald (Ed.), The Sense of Humor: Explorations of a Personality Characteristic (pp. 231-270). Berlin and New York: Mouton de Gruyter.

Savaş, S. (2013).The Effects of the Use of Humor at Seventh Grade on Student Achievement in Turkish Courses.Karaelmas Journal of Educational Sciences, 1, 176-186.

Scarborough, J. (2014). Student Perceptions of Instructional Use of Humor in the Online Classroom (Doctoral dissertation). Retrieved from https://pqdtopen. proquest.com/doc/1566948213.html?FMT=ABS

Schmitz, J. R. (2002). Humor as a pedagogical tool in foreign language and translation courses. Humor - International Journal of Humor Research, 15(1), 89-113.doi: 10.1515/humr.2002.007

Segrist, D. J. \& Hupp, S. D. A. (2015). This Class is a Joke! Humor as a Pedagogical Tool in the Teaching of Psychology. OTRP Online. Retrieved from https://teachpsych.org/Resources/Documents/otrp/resources/segrist15.pd $\mathrm{f}$

Stuart, W. D., \& Rosenfeld, L. B. (1994). Student perceptions of teacher humor and classroom climate. Communication Research Reports, 11, 87-97. doi: 10.1080/08824099409359944

Sümer, N. (2000). Yapısal eşitlik modelleri: Temel kavramlar ve örnek uygulamalar; [Structural equation models: Basic concepts and sample applications]. Turkish Psychology Literature, 3(6), 49-74. 
Sümer, M. (2008). Pre-service early childhood educators' styles of stress management and a comparison of their humor styles according to some variables (Master's thesis). Retrieved from

https://tez.yok.gov.tr/UlusalTezMerkezi/tezSorguSonucYeni.jsp

Topal, Z. (2013). Development of attitude towards humour in elementary school $4^{\text {th }}-8^{\text {th }}$ graders (Master's thesis). Retrieved from https://tez.yok.gov.tr/UlusalTezMerkezi/tezSorguSonuc Yeni.jsp

Topçuoğlu, H. (2007). Importance of Humour in Education. Bilim ve Aklın Aydınlı̆̆ında Ĕ̈itim Dergisi, 84, 38-43.

Torok, S. E., McMorris, R.F., \& Lin, W-C. (2004). Is humor an appreciated teaching tool? Perceptions of professors' teaching styles and use of humor. College Teaching, 52(1), 14-20.doi:10.3200/CTCH.52.1.14-20

Vural, A. (2004). The Currency and Importance of Humour and Laughter in Human Life (Master's thesis). Retrieved from https://tez.yok.gov.tr/UlusalTezMerkezi/tezSorguSonucYeni.jsp

Wanzer, M. B. (2002). Use of humor in the classroom: The good, the bad, and the not-so-funny things that teachers say and do (pp. 116-125). In Chesebro, J. L. \& McKroskey, J. C., Communication for Teachers. Boston: Allyn and Bacon.

Yardımcı, İ. (2010). The Concept of Humor and Its Place in Art. Uşak University Journal of Social Sciences, 3(2), 1-41.

Yerlikaya, N. (2007). The relationship between humor styles and coping styles of high school students (Master's thesis). Retrieved from https://tez.yok.gov.tr/UlusalTezMerkezi/tezSorguSonucYeni.jsp

Yılmaz, V. \& Çelik, H. E. (2009). LISREL ile yapısal eşitlik modellemesiI: Temel kavramlar, uygulamalar, programlama. [Structrual equation modeling via LISREL: Basic concepts, applications and programming.] Ankara: Pegem Akademi.

Yirci, R., Özdemir, T., \& Kartal, E. S. (2016). School Administrators' Humour Orientations. Journal of Human and Social Sciences Researches, 5(8), 2479-2495.

Yue, X., Jiang, F., Lu, S. \& Hiranandani, N. (2016). To be or not to be humorous? Cross-Cultural Perspectives on Humour. Frontiers in Psychology, 7, 1-10. Retrieved from https://www.ncbi.nlm.nih.gov/pmc/articles/PMC5048456/pdf/fpsyg-0701495.pdf 
Zhou, C. (2015). Students' Perceptions of Humor and Creativity in ProjectOrganized Groups (POGs) in Engineering Design Education in China. International Journal of Chinese Education, 4(2), 162-179. doi: 10.3390/su10010114

Ziv, A. (1988). Teaching and learning with humor: Experiment and replication. The Journal of Experimental Education, 57(1), 4-15.doi: 10.1080/00220973.1988.10806492

SerkanUsal is an assistant professor at Kahramanmaras Sutcu Imam University of Turkey

ReyhanAgcam is an assistant professor at Kahramanmaras Sutcu Imam University of Turkey

Mikail Aydemir is a mathematics teacher at Ministry of National Education (MoNE), Turkey.

Contact Address: Kahramanmaraş Sutcu Imam Universitesi Egitim Fakultesi Avsar Yerleskesi, 46050 Onikişubat/ Kahramanmaraş, Turquía

E-mail: serkan-unsal09@ hotmail.com 